\title{
USE OF DISTRIBUTED CONTROL STRUCTURES, CRUSHING AND BREAKING COMPLEXES
}

\author{
Marynych I.A. (Ukraine ) Email: Marynych328@scientifictext.ru
}

\author{
Marynych Ivan Anatolievich - PhD of technical sciences, Senior Lecturer, \\ DEPARTMENT OF INFORMATION SCIENCE, AUTOMATION AND CONTROL SYSTEMS, \\ STATE INSTITUTION OF HIGHER EDUCATION «KRYVYI RIH NATIONAL UNIVERSITY», KRIVOY ROG, UKRAINE
}

\begin{abstract}
: the article application of distributed control systems, crushing and breaking complexes mining factory. Attention is paid to the main factors affecting the energy efficiency of crushing and grinding processes. The expediency of representing a crushing and grinding complex in the form of a structure with distributed parameters is justified. Presentation of crushing, grinding complex mining and processing enterprise in the form of structures with distributed parameters to minimize the unit cost of the processes of crushing, grinding and achieve maximum line speed and reduce the load on the final stage - the grinding, which in turn contributes to the overall reduction in energy consumption.

Keywords: crushing, grinding complex, distributed system of adaptive control, distributed control, the function of reducing the size of the ore.

\section{ПРИМЕНЕНИЕ РАСПРЕДЕЛЕННЫХ СИСТЕМ УПРАВЛЕНИЯ ДРОБИЛЬНО-ИЗМЕЛЬЧИТЕЛЬНЫМИ КОМПЛЕКСАМИ Маринич И.А. (Украина)}

\author{
Маринич Иван Анатольевич - кандидат технических наук, стариий преподаватель, \\ кафедра информатики, автоматики и систем управления, \\ Государственное высшее учебное заведение \\ Криворожский национальный университет, г. Кривой Рог, Украина
}

\begin{abstract}
Аннотация: в статье рассматривается применение распределенных систем управления дробильноизмельчительным комплексом горно-обогатительного комбината. Уделено внимание основным факторам, влияющчи на энергоэффективность процеессов дробления и измельчения. Обоснована целесообразность представления дробильно-измельчительного комплекса в виде структурь с распределенньми параметрами. Представление дробильно-измельчительного комплекса горнообогатительного комбината в виде структуры с распределенными параметрами позволяет минимизировать удельные затраты на проиессы дробления - измельчения и добиться максимальной производительности технологической линии и снижения нагрузок на конечную стадию - измельчение, что, в свою очередь, способствует общему снижению энергопотребления.

Ключевые слова: дробильно-измельчительный комплекс, распределённая система адаптивного управления, распределенный регулятор, функиия сокращения крупности руды.
\end{abstract}

Сокращение крупности кусковой руды является необходимым этапом в её подготовке к обогатительному переделу с целью полного раскрытия содержащегося в ней полезного компонента. На современных горно-обогатительных комбинатах этот процесс выполняется дробильноизмельчительными комплексами, которые включают в себя несколько стадий дробления и измельчения исходного сырья.

Энергоэффективность технологического процесса характеризуется абсолютной или удельной величиной потребления или потерь энергоресурсов на производство конечного продукта. Расход энергии на дробление и измельчение руды зависит от многих параметров, важнейшими из которых являются: производительность, степень измельчения, структурно-механические свойства перерабатываемого материала, его влажность и другие.

Уменьшить негативное влияние изменений характеристик исходной руды на энергопотребление дробильно-измельчительных комплексов горно-обогатительного комбината и при этом максимизировать их производительность по готовому продукту заданного качества возможно только при наличии эффективного автоматизированного управления технологическим процессом $[1,2]$.

Вместе с тем, существующие системы автоматизированного управления процессами дробления и измельчения руды, вследствие устаревших методов идентификации и моделирования объектов управления, которые используются при их разработке и эксплуатации, не обеспечивают качественного формирования и поддержания оптимальной степени измельчения перерабатываемого сырья в условиях изменяющихся физико-механических и химико-минералогических его характеристик, что негативно отражается на качестве конечного продукта и энергоэффективности технологического процесса. 
Учитывая, что основными условиями оптимизации управления дробильно-измельчительным комплексом является формирование гранулометрического состава руды, обеспечивающего необходимое качество ее обогащения в соответствии с текущими характеристиками перерабатываемого сырья при минимизации удельных затрат на процессы сокращения его крупности и максимальной производительности технологической линии [1]. А процессы дробления, измельчения и классификации носят случайный характер и в любой момент времени характеризуются переходными вероятностями, а сам дробильно-измельчительный комплекс занимает большую территорию и территориально распределен в пространстве, целесообразно рассматривать его как систему с распределенными параметрами функции сокращения крупности перерабатываемого сырья [2, 3].

Поэтому актуальной является разработка математических моделей дробильно-измельчительного комплекса на базе структуры с распределёнными параметрами функции сокращения крупности руды [1]. А также разработка принципов согласованного адаптивного управления многостадиальным процессом сокращения крупности руды путем формирования оптимальной функции распределения её частиц по крупности для выходных продуктов дробильных и измельчительных агрегатов каждой стадии с учётом их производительности и удельных энергозатрат на процесс [2].

Таким образом, разработка принципов, структуры и системы энергоэффективного адаптивного управления дробильно-измельчительным комплексом горно-обогатительного комбината на базе модели c распределёнными параметрами функции сокращения крупности руды, обеспечивающего с минимальными энергозатратами формирование и поддержание оптимальной производительности и гранулометрического состава выходных продуктов взаимосвязанных дробильных и измельчительных агрегатов в условиях неполной информации о характеристиках объекта управления, существенно изменяющихся во времени - позволяет улучшить качество математического описания объекта управления и за счет этого оптимизировать технологический процесс и уменьшить удельные энергозатраты на производство конечного продукта [4].

\section{Список литературы / References}

1. Маринич И.А. Математическое описание дробильно-измельчительного комплекса горнообогатительного комбината в виде структуры с рапределенными параметрами // Вісник Криворізького технічного університету, 2011. № 29. С. 250-256.

2. Моркун В.С. Адаптивные системы оптимального управлення технологическими процессами / В.С. Моркун, АА. Цокуренко, И.А. Луценко. Кривой Рог: Минерал, 2005. 261 с.

3. Marynych I.A. Reason for application of intelligent systems for disintegrating complex control. Metallurgical and Mining Industry, 2014. № 6. P. 25-29.

4. Пат. на корисну модель № 72410 Україна, МПК 2012.01. Спосіб управління дробильноподрібнювальним комплексом / Маринич I.А. № 201110455; заявл. 29.08.2011; опубл. 27.08.2012. Бюл. № 16. 